\title{
REESCALONAMENTO DA DÍVIDA EXTERNA BRASILEIRA: UM EXEMPLO DE INTEGRAÇĀO JURÍDICO-ECONÔMICA NO FINAL DO SÉCULO
}

\author{
Fábio Nusdeo \\ Professor Associado do Departamento de Direito Econômico-Financeiro \\ da Faculdade de Direito da Universidade de São Paulo
}

Resumo:

O artigo procura apresentar uma visão geral do problema da dívida externa brasileira, colocando-o sob uma perspectiva estrutural, com vistas a ressaltar não decorrer a mesma de uma mera conjuntura momentânea, mas sim de uma profunda alteração nas relações econômicas internacionais que se processou em virtude da conjugação de uma série de fatores internos e externos que são, brevemente, analisados.

Após uma rápida introdução histórica, o trabalho focaliza o surgimento do mercado de eurodólares e o seu subseqüente desenvolvimento, sobretudo a partir dos dois choques do petróleo quando, através dele, se processou a chamada reciclagem dos petrodólares.

E, a seguir, analisada a instrumentação jurídica para o reescalonamento da dívida externa, apresentando-se, ao término, algumas sucintas conclusões.

Abstract:

The article purports to present a general view of the Brazilian foreign debt crisis departing from a structural approach, in order to stress that same does not derive from a mere unfavourable phase or cycle of the economy, but results from a substantial transformation in the international economic set, caused, in turn, by a conjunction of factors which are briefly examined.

Starting with a small introduction, the paper focuses on the creation and development of the eurodollar market in particular as a consequence the two oil crisis when it promoted the so called petrodollar recycling.

Subsequently, the legal architecture established for the reescheduling of the debt is also analysed. At the end some succinct conclusions are drawn from the text. 
INTRODUÇÃO.

A chamada crise da dívida externa representa, sem dúvida, uma das marcas mais características da economia internacional neste fin de siècle que é, também, um fim de milênio.

Como salientado, com muita propriedade, pelo professor Celso Lafer, em conferência proferida nesta Faculdade, não se trata de um momento ou de uma época de crise, como tantas já vividas anteriormente, mas, sim, da crise de uma época. Ela não é, pois, meramente conjuntural por representar o epifenômeno de toda uma estrutura criada pela conjugação de diversos fatores que passaram a caracterizar a economia mundial e as relações entre seus principais segmentos a partir da década de sessenta.

Para o bom entendimento do problema, impõe-se um breve escorço histórico da evolução de cada um desses fatores a fim de se chegar a uma percepção tão nítida quanto possível de como eles se foram imbricando, para gerar o quadro, a um tempo inédito e dramático, com que vem se defrontando o Brasil e a maioria dos países da América Latina, além de outros, há cerca de dez anos, quadro esse que não é de molde a se alterar substancialmente no decorrer das próximas décadas.

Neste trabalho procurar-se-á analisar, de início, o panorama dos empréstimos internacionais até a Segunda Guerra Mundial e a inserção nele do Brasil, para, a seguir, apresentar-se o surgimento e o desenvolver de uma nova fonte para esses financiamentos representada pelo chamado mercado do eurodólar cuja aparição se deu após o término daquele conflito.

Proceder-se-á, depois, à discussão dos aspectos político e econômico do desenvolvimento brasileiro, sob a égide do movimento militar ocorrido em 1965 no bojo da Revolução de 1964. Uma nova secção examinará os efeitos dos dois choques do petróleo, de 1964 e 1969, com a chamada reciclagem dos petrodólares e suas repercussões sobre a economia nacional. Prosseguindo, procurar-se-á caracterizar o impasse da dívida e a materialização do risco político inerente a toda operação internacional para se chegar a uma descrição dos mecanismos jurídicos para o equacionamento da nova situação e, imediatamente após, a evolução dos mesmos até o recentíssimo "Acordo em Princípio" que representa uma nova visão do problema da dívida, com a 
indicação de um ou outro detalhe de maior relevância legal no contexto do sistema de reescalonamento adotado. Algumas conclusões finalizam o trabalho.

A fim de não alongar em demasia o presente artigo e evitar desbordamentos desnecessários, não se fará menção específica a acordos e a esquemas de reestruturação aplicados a outros países em situação semelhante à do Brasil, bastando indicar que, em linhas gerais, eles se situam em paralelo àqueles adotados pelo Brasil, guardadas, naturalmente, as características e peculiaridades próprias de cada um.

Após essa singela apresentação inicial, passa-se, agora, a discorrer sobre os ítens atrás anunciados.

\section{O BRASIL E OS FINANCIAMENTOS INTERNACIONAIS ATÉ A DÉCADA DE SETENTA.}

É corriqueiro o conhecimento de que o Brasil, como nação, já nasceu endividado. Com efeito, para o reconhecimento do novo império brasileiro, exigira Portugal uma indenização pelos dispêndios realizados na excolônia - depois Reino Unido - de cerca de 2 milhões de libras esterlinas. Como, naturalmente, tal soma era indisponível na época, o Marquês de Barbacena foi encarregado pelo Imperador de obter um empréstimo na praça de Londres, conseguindo-o junto à Casa Rothschild, com o que se iniciou a história da dívida externa brasileira.

É quase pitoresco apontar que, com ela, iniciaram-se também as suspeitas de locupletamento indevido de agentes do governo em negócios da espécie, já que o inefável Marquês que mais tarde negociaria o segundo casamento do Imperador foi alvo, no Parlamento, de acusações de ter embolsado uma não despicienda comissão pelos seus préstimos no episódio.

Naquela época e assim continuou por mais de um século os empréstimos internacionais eram concedidos primordialmente por banqueiros londrinos e, basicamente, pelo menos no que tange a países da periferia européia, a governos ou a grandes concessionários de serviços públicos que tinham o respaldo governamental, inclusive via contratos que lhes asseguravam o monopólio da exploração em suas áreas de atuação. Em grande número de 
casos, governos e concessionárias se financiavam por meio de títulos (apólices) colocadas nos mercados europeus sob a égide dos grandes bancos.

O Império não desenvolveu a rotina de captação de recursos no exterior. Já na República, a Constituição de 1891 estabelecera um regime curioso para as captações oficiais, submetendo o endividamento federal a um conjunto rígido de autorizações que, paradoxalmente, não se aplicavam aos governos estaduais e municipais. Isso deu origem a uma caótica pulverização de contratação de empréstimos e de colocação de títulos no exterior por parte dessas esferas executivas o que causou, ainda no fim do século, uma dificuldade de pagamento, levando o Presidente Campos Salles a negociar em 1898, pela primeira vez, uma consolidação da dívida externa a que se deu o nome de funding com o reescalonamento de prazos de vencimento com vistas ao alívio da balança de pagamentos. Novo reescalonamento ocorreria em 1914 com Hermes da Fonseca.

Já sob o governo provisório, instalado como decorrência da Revolução de 1930, decretou-se no ano seguinte uma moratória, em parte justificada pela crise de 1929 que reduzira drasticamente as exportações de café, base da receita cambial àquela época. Em 1961 o recém-empossado governo de Jânio Quadros também conseguiu, sob os auspícios do Presidente dos Estados Unidos, John F. Kennedy, uma extensão de prazos.

O endividamento do Brasil do setor público e do privado situava-se, então, ao redor de 3 bilhões de dólares, chegando a 3.7 bilhões em 1964 quando o novo governo solicitou e obteve um stand-by loan do Fundo Monetário Internacional e algumas facilidades para pagamento junto aos banqueiros privados.

Como a prioridade essencial do primeiro governo após a Revolução de 1964 era representada pelas reformas institucionais tidas como indispensáveis para permitir a estabilidade monetária e a retomada, em bases sadias, do desenvolvimento econômico, não houve até $1967 \mathrm{e}$, mesmo, até o fim da década, preocupação maior em se proceder a uma captação maciça de recursos externos, muito embora o fluxo de capitais de empréstimo tenha tido os seus canais normativos perfeitamente estruturados com a regulamentação em 1965 da Lei n. 4.131, de 1962 - a lei do capital estrangeiro e a edição, logo mais, da Resolução n. 63, pelo Conselho Monetário Nacional, estabelecendo a figura 
do repasse de recursos externos obtidos por bancos nacionais e redistribuídos fracionadamente a tomadores finais do país.

Foi, no entanto, a partir dos anos setenta que se iniciou a grande escalada do endividamento brasileiro, colocado como uma peça essencial ao projeto Brasil-potência, então acalentado e delineado pelo terceiro governo revolucionário instalado em 1969.

Havia, na época, uma generalizada confiança na capacidade nacional de captar recursos em grande escala, bem como na de pagá-los na época dos vencimentos. Tal otimismo decorria dos resultados altamente favoráveis obtidos pelas exportações que no período 1964-1971 passaram da casa dos 1.5 bilhão de dólares para cerca de 12 bilhões. Tal desempenho deveu-se não apenas a medidas internas de fortalecimento e racionalização do setor, como também a uma conjuntura internacional extremamente favorável, representada por uma fase de expansão e afluência nos grandes mercados importadores e por uma expressiva melhora ao redor de $20 \%$ nas relações de intercâmbio (terms of trade) entre os produtos componentes das pautas exportadora e importadora do país.

\section{II - O SUPRIMENTO INTERNACIONAL DE RECURSOS NO APÓS GUERRA - O MERCADO DE EURODÓLARES.}

Enquanto as coisas assim evoluíam no Brasil, profundas alterações também se fizeram sentir do outro lado, ou seja, no campo dos supridores dos recursos tão avidamente procurados pelos tomadores subdesenvolvidos.

Até o segundo grande conflito mundial o tema não oferecia maiores indagações ou complexidades. Os grandes bancos dos vários países desenvolvidos, particularmente os ingleses, destinavam uma parte de seus recursos a mutuários do exterior, seja para o financiamento do comércio internacional, seja o suporte a investimentos industriais ou agrícolas e, ainda, a projetos de infra-estrutura conduzidos por governos ou empresas estatais. A atividade desses banqueiros englobava, ademais, a colocação de títulos junto a poupadores locais com ou sem o compromisso de underwriting.

A instrumentação legal desses empréstimos não apresentava problemas de maior monta. Tratava-se de contratos de mútuo celebrados sob a 
égide das leis de cada país onde tivesse sede o mutuante, sempre com forte marca, do padrão anglo-saxão de contratos da espécie.

No entanto, pouco depois de findar-se a Segunda Guerra Mundial, começa a surgir na praça de Londres um mercado sui generis de fundos para empréstimos, alimentado por alguns depósitos feitos em dólares americanos junto a bancos daquela praça, sobretudo por sociedades sediadas nos Estados Unidos. Três fatores principais deram origem a esse fenômeno, sem dúvida, um dos mais marcantes nas finanças internacionais da atualidade.

Em primeiro lugar, deu-se a volta à convertibilidade monetária das grandes nações do primeiro mundo, já em dezembro de 1958.

Em segundo lugar, a crise da libra esterlina, ocorrida em 1957, levou a uma série de limitações impostas pelo governo britânico ao movimento de acceptances em libras no mercado londrino, privando, assim, o mundo ocidental de um de seus mais tradicionais instrumentos de financiamento. Em contrapartida, o mesmo governo britânico passou a permitir aos bancos ingleses receberem depósitos em moeda americana, os quais foram utilizados nos financiamentos internacionais com base no know-how britânico no setor.

Em terceiro lugar, veio se somar a esses dois fatores a adoção pelos Estados Unidos em 1967-68 de uma política monetária extremamente severa e restritiva com vistas a jugular tendências inflacionárias que vinham se acumulando até então. $O$ célebre "Regulation $Q$ " do Federal Reserve, editado no bojo do Banking Act de 1933, passa a ser aplicado com vigor, restringindo o crédito e elevando as taxas de juros para empréstimos, enquanto estabelecia um teto para os juros pagos a depositantes.

$\mathrm{O}$ resultado foi o crescimento extraordinário do mercado de eurodólar com uma pletora de fundos para ele canalizados por empresas americanas, particularmente as de caráter multinacional e, igualmente, com significativo crescimento da procura por tais fundos também por sociedades americanas, ansiosas por contornar as restrições domésticas no suprimento de recursos.

Expandiu-se, assim, e se consolidou o mercado de eurodólares, também chamado de eurodivisas, passando a atrair depósitos de todas as partes do mundo, graças sobretudo, ao seu status de extraterritorialidade, já que seus fundos não estão sujeitos a qualquer autoridade monetária que possa aplicar-lhes 
os instrumentos habituais da política monetária interna, tais como, contingenciamento de crédito, depósitos compulsórios, tetos para juros e outros que tais. Em termos jurídicos ele ensejou o desenvolvimento de uma espécie de lex mercatoria para o campo dos empréstimos internacionais, com seus contratos calcados no estilo anglo-saxão cada vez mais padronizados, seus mecanismos próprios de fixação de juros, tudo sem intervenção estatal. Em suma, esse mercado passou a corresponder a uma espécie de bolsão de liberdade em meio a um mundo de mercados financeiros nacionais estritamente regulamentados pelos respectivos bancos centrais.

\section{OS DOIS CHOQUES DO PETRÓLEO E A RECICLAGEM DOS PETRODÓLARES.}

Estava assim o mercado de eurodólares perfeitamente estruturado e em processo de constante ampliação quando sobreveio o primeiro choque do petróleo, em outubro de 1974, que veio convulsionar a economia mundial, gerando de início uma generalizada escassez de moeda forte, já que os preços triplicados do óleo implicaram o comprometimento proporcionalmente maior das receitas de exportação da generalidade dos países com esse ítem de importação, operando-se a conseqüente drenagem de moeda forte em direção aos produtores, membros da OPEP. Esses últimos viram-se, assim, da noite para o dia, abarrotados de recursos que, dada a incipiência de suas economias, não tinham condições de prontamente utilizar, seja em consumo, seja em investimentos.

A solução natural foi a de colocá-los no sistema financeiro internacional, provocando o seu retorno ao mercado de eurodólar, que passou, assim, a inflar-se extraordinariamente. Não apenas a oferta de moeda para empréstimos se elevou, como também a sua procura, pois a única forma a curto prazo de as nações importadoras de petróleo arcarem com os novos preços sem paralisar ou reduzir em excesso as suas atividades produtivas era a de tomar esses recursos a fim de suprir as inevitáveis insuficiências de suas balanças comerciais.

Inicia-se, destarte, o chamado processo de reciclagem dos petrodólares, via mercado de eurodivisas, com a expansão extraordinária dos 
empréstimos internacionais. $\mathrm{O}$ movimento, de caráter mundial, teve, porém, no Brasil da época, um dos seus pontos culminantes. $\mathrm{E}$ isso se explica, basicamente, por uma razão política.

Na realidade, a Revolução de 1964 teve, em si, um escopo limitado: o de "pôr a casa em ordem", com o saneamento financeiro, implantação de razoável estabilidade monetária e reformas diversas de caráter institucional na estrutura do sistema econômico. Sucede que essa corrente por assim dizer "minimalista", que predominou no início da nova ordem, foi sendo suplantada por uma outra de visão "maximalista", cuja orientação era a de manter o estado de exceção institucional revolucionário pelo período necessário à implantação e operacionalização de todas as reformas, quando, então, o Brasil ter-se-ia transformado numa potência de porte médio. Como é sabido, essa última corrente impôs-se definitivamente com a nova revolução ocorrida com a edição do Ato Institucional n. 5, em dezembro de 1968.

Nessas condições, o regime, instalado por tempo indeterminado, buscou a sua legitimidade não pela origem - o consenso da nação manifestado por eleições livres - mas sim pelos resultados com que acenava: o Brasilpotência.

E claro que em tal contexto, tornava-se impensável para o establishment brasileiro da época, qualquer redução no ritmo dos investimentos e do crescimento da economia que caracterizavam o tão decantado "milagre brasileiro". E, assim, lançou-se o país, na voragem dos acontecimentos mundiais, ou seja, adentrou a ciranda dos petrodólares, virtualmente impondo por meios diversos às empresas brasileiras, públicas e privadas, o recurso ao endividamento externo, tais como a elevação dos juros internos acima do nível internacional a fim de tornar tais empréstimos atrativos. Utilizou-se também o mecanismo das operações simbólicas de câmbio para permitir que tomadores de recursos externos fizessem um hedge cambial, mediante depósitos em moeda estrangeira junto ao Banco Central, a fim de atender às fases de liquidez em cruzeiros não correspondentes aos períodos de exigibilidade das remessas relativas aos empréstimos tomados. Especificamente no setor público, projetos eram febrilmente elaborados, não tanto porque sua implantação fosse imprescindível, mas principalmente porque eles gerariam divisas, via financiamento externo. 
Dentro do quadro acima descrito, fácil será entender a razão do crescimento explosivo do endividamento externo brasileiro que por volta de 1982 atingia a casa dos 120 bilhões de dólares. A essa cifra chegou-se não apenas pelo movimento contínuo de empréstimo sobre empréstimo, mas também pela ocorrência de um fato, ou melhor, de um ato perturbador do relativo equilibrio em que se encontravam as taxas de juros internacionais. Ele se deveu à política contracionista adotada pelo Federal Reserve americano, no fim da década de setenta até início da de oitenta, a fim de conter pressões inflacionárias internas e diminuir o ritmo de atividade, justamente para não agravar a balança de pagamentos. A contração monetária americana levou a prime rate para os píncaros o que, pelo princípio dos vasos comunicantes, acarretou a desmesurada elevação da LIBOR - a taxa flutuante de juros praticada no mercado de eurodivisas. Essa que tinha variado, basicamente, entre 7 e $12 \%$ chegou a atingir por um bom período o patamar dos $20 \%$, superando-o mesmo em alguns meses.

Desnecessário frisar o agravamento trazido por essa situação para a balança de pagamentos do país, na qual apenas o ítem juros passava a absorver anualizadamente algo ao redor dos 24 bilhões de dólares, sem se contar com todas as importações, entre elas a do próprio petróleo, cujos preços com o segundo choque de 1979 haviam mais do que duplicado em relação aos do primeiro choque, varando o nível de 30 dólares o barril.

\section{IV - OS INSTRUMENTOS DE FORMALIZAÇÃO PARA O REESCALO- NAMENTO DA DÍVIDA.}

A crise da época, como dizia Celso Lafer, desencadeou-se sem peias e a partir de 1982 com a guerra das Falklands e a bancarotta mexicana, levando ao movimento de reestruturação das dívidas externas de diversos países, inclusive o Brasil.

É interessante, porém, ressaltar que naquele momento - 1982-1983 - a chamada comunidade financeira internacional e os próprios governos não se haviam dado conta, pelo menos aparentemente, do caráter duradouro e estrutural da crise, de tal sorte que o selı equacionamento jurídico ficou limitado no tempo. Com efeito, parece hoje, pelo menos estranho, que os quatro grandes projetos, como foram chamados, se corporificassem em contratos com prazo de 
apenas um ano. Claramente, tal defasagem entre a realidade econômica e o seu tratamento jurídico-político não se devem exclusivamente a uma possível falta de percepção. Outras explicações devem ser procuradas na situação enfrentada pelos vários bancos no seu relacionamento com suas respectivas autoridades monetárias que, àquela época, diante de uma prorrogação a longo prazo da dívida externa de países inteiramente insolventes, possivelmente exigiriam provisões que a grande maioria deles não estaria em condições de fazer. Havia, ainda, o aspecto didático a ser considerado: a comunidade financeira não estava preparada para acenar aos devedores, indistintamente, com uma tal prorrogação. $\mathrm{E}$, ademais, parecia conveniente realizar, de início, um "ensaio" dos mecanismos legais apenas então criados ou adaptados para testar o seu funcionamento e a sua adaptabilidade a um estado de coisas tão inusitado, quanto complexo.

Chega-se, assim, ao mês de fevereiro de 1983, quando são assinados quatro grandes contratos entre o Banco, Central de um lado e os bancos credores de outro, comparecendo a República Federativa do Brasil como garantidora. Cada um deles preenchia um escopo específico, mas complementavam-se entre si, para formar um conjunto sincronizado apto a escorar as finanças internacionais do Brasil e a enfrentar a crise que marcava uma época. Os quatro contratos são a seguir descritos em suas linhas gerais.

1 - "Credit and Guaranty Agreement"

Trata-se, pura e simplesmente, de um aporte de novos recursos em moeda (New Money) que os bancos credores fizeram ao Banco Central do Brasil, sob a forma de empréstimos a longo prazo, no montante de 4,5 bilhões de dólares. Tratou-se de um contrato-padrão de mútuo internacional, contendo, porém, algumas cláusulas especiais, adaptadas aos seus objetivos próprios. Entre elas por sua relevância devem ser mencionadas as relativas ao prepayment (pagamento antecipado) e ao relending (reempréstimo), segundo a qual o Banco Central brasileiro passava a ter a obrigação de, em qualquer momento, pagar antecipadamente determinados montantes do empréstimo recebido, desde que solicitação nesse sentido fosse a ele encaminhada por qualquer banco mutuante. Tal solicitação, porém, somente seria cabível se os recursos correspondentes ao prepayment fossem colocados à disposição de um novo mutuário brasileiro indicado pelo banco interessado ao Banco Central, mediante uma notice of 
prepayment. Daí o nome relending, pois o que na realidade ocorria era um pagamento antecipado da dívida do Banco Central sob esse contrato, mas condicionada tal antecipação a um novo empréstimo a ser concedido pelo banco pré-pago a uma empresa ou entidade, de sua escolha, sediada no país, seja do setor público, seja do setor privado.

O contrato celebrado entre o banco e seu novo mutuário, chamado de Additional Loan Agreement, tinha os scus parâmetros todos juros, comissões, encargos diversos, prazo mínimo, etc. já previamente fixados pelo Credit and Guaranty Agreement, constituindo-se num empréstimo absolutamente normal e rotineiro concedido por um banco estrangeiro a um tomador nacional. Como tal, sujeitava-se a registro no Banco Central para fins de remessas de juros, repatriamento do principal (o que, na prática, não ocorreria em virtude do outro contrato a ser a seguir examinado), aplicação de suas cláusulas quanto a garantias e tudo o mais. A única diferença, irrelevante aliás, decorria do fato de estarem os recursos mutuados, já no Brasil, com o Banco Central e não serem trazidos de fora por ocasião do saque pelo mutuário.

\section{2 - "Deposit Facility Agreement"}

A segunda base e sem dúvida, a mais importante - montada para o equacionamento do problema da dívida externa foi representada por este segundo contrato, também celebrado pelo Banco Central do Brasil com os diversos bancos credores tendo a República como garantidora.

O seu objeto não foi o de trazer novos recursos em moeda do exterior, mas sim o de evitar a saída dos recursos já no Brasil, em mãos de tomadores nacionais por via de contratos de mútuo anteriormente celebrados e que se venceriam daí em diante. Explica-se, pois, o nome do documento: Deposit Facility Agreement, ou seja, um empréstimo (facility) que os bancos internacionais faziam ao mesmo Banco Central, concordando em que as parcelas do principal a eles devidas pelos mutuários do país fossem sendo depositadas, à medida em que se vencessem, junto ao mesmo Banco Central e não remetidas aos mesmos bancos, seus credores no exterior, como assegurado pelos respectivos certificados de registro concedidos à época da contratação.

Tais depósitos eram, evidentemente, denominados em moeda estrangeira, constituindo-se mediante a celebração de operações simbólicas de 
câmbio. Ficava, assim, o Banco Central como devedor não por se subrogar na dívida do mutuário original, mas, pura e simplesmente, pelo fato de essa dívida a do mutuário original - ter sido por este saldada mediante o depósito junto ao Banco Central determinada ou autorizada pelo próprio credor externo.

Em outras palavras, com o depósito acima referido, desobrigava-se cabalmente o devedor local, pára todos os efeitos legais, liberando inclusive, quaisquer coobrigados tais como eventuais garantidores no Brasil ou no exterior.

Ora, para todos os efeitos, tais recursos à medida em que iam sendo depositados no Banco Central, sempre identificados pelos certificados de registro originais, passavam a ter a mesma natureza daqueles outros provenientes do exterior ao abrigo do contrato anteriormente comentado Credit and Guaranty Agreement - e assim, passavam a estar sujeitos basicamente ao mesmo tratamento, passíveis, portanto, de serem igualmente utilizados pelos bancos credores - titulares dos depósitos - para reempréstimo (relending) nas mesmas condições daqueles outros fundos. Mais ainda, os recursos de um e de outro dos projetos Projeto I (Credit and Guaranty Agreement) e Projeto II (Deposit Facility Agreement) - poderiam, perfeitamente, ser mesclados pelos seus titulares, de modo a compor um único Additional Loan Agreement a ser concedido a novos tomadores nacionais.

A rigor, foi este contrato o suporte fundamental de todo o programa de ajuste então adotado porque, na realidade, foi ele o responsável pela rolagem do estoque da dívida então existente. Por essa razão ele será mantido, com renovações, é claro, por dez anos, chegando, levemente transformado até o presente ano de 1992 como se verá logo mais.

\section{3 "Trade Finance"}

O terceiro projeto integrante do conjunto que compôs o reescalonamento do ano de 1983 foi o relativo às chamadas linhas comerciais, destinadas ao financiamento do comércio exterior do país nos dois sentidos.

Tenha-se presente que o acerto geral com os credores teve por objeto sempre o estoque da dívida, ou seja, o seu principal acumulado ao longo dos anos e engrossado pelo New Money do Projeto I. O seu pressuposto era o de regular manutenção do seu serviço no que tange aos juros. No entanto, como já assinalado, somente o comprometimento com esse encargo, à época, significava 
algo ao redor de US\$20 a 24 bilhões, deixando da receita exportadora, apenas, e escassamente, o indispensável para o suprimento de combustíveis. Daí a necessidade de um terceiro esquema, voltado à sustentação da capacidade importadora do país que, se assim não fosse, quedar-se-ia economicamente inerme.

O mecanismo operacional do Projeto III consistiu no suprimento de linhas comerciais rotativas pelos diversos bancos, mediante recursos colocados à disposição do Banco Central do Brasil que os deveria manter na praça de New York. Tais recursos seriam utilizados pelos bancos para financiar basicamente as importações brasileiras, o que se fazia mediante saque pelo banco financiador sobre a sua linha junto ao Banco Central, destinados os recursos a pagamento direto ao exportador estrangeiro de bens por ele vendidos ao Brasil. A formalização dava-se mediante contrato com o importador local que assim ficava devedor do banco estrangeiro. No caso de financiamento à exportação, o fluxo seria o inverso.

De qualquer maneira, pagos os financiamentos em questão, os respectivos fundos voltavam a ficar à disposição do Banco Central na praça de New York para subseqüentes operações, o que decorria do caráter rotativo das linhas de crédito.

4 - Depósitos junto a agências no exterior

O último quadripé do esquema implantado em 1983 foi representado pelo compromisso por parte dos bancos internacionais de manter um montante mínimo de depósitos junto às agências dos bancos nacionais no estrangeiro. Tal providência se impunha pelo fato de essas agências terem, antes da crise, utilizado os depósitos por elas captados para, também, financiarem empresas nacionais quer na modalidade trade finance quer sob a forma de mútuos-padrão. Nessas condições, eram também credoras da nacionais em moeda estrangeira, sujeitas aos mesmos percalços e em posição idêntica à das demais instituições financeiras sediadas no exterior quando a crise da dívida se desencadeou. Necessitavam assim de um nível mínimo de recursos para a manutenção de suas atividades, o que foi equacionado por esse projeto.

Ficou, assim, constituída juridicamente a estrutura montada para permitir ao país superar as severíssimas dificuldades decorrentes de um processo 
pouco responsável de endividamento maciço desenvolvido sob a égide da idéia força do Brasil-potência ao longo de uma década e meia, com ênfase especial a partir do primeiro choque do petróleo, como visto.

Naturalmente, os acordos acima, envolvendo o Banco Central e a chamada comunidade financeira internacional, deram origem a toda uma parafernália normativa representada por resoluções, circulares, comunicados e demais atos das autoridades monetárias destinados a implementar os diversos projetos tal como acordados. A importação, por exemplo, foi minuciosamente regulamentada pelo próprio Banco Central, através de resoluções que condicionavam o licenciamento de quase toda a pauta à comprovação de estar a operação lastreada em contrato de financiamento com prazos previamente estipulados em função do tipo e valor de cada ítem a ser importado. Inúmeros atos normativos detalharam, por outro lado, todos os trâmites de caráter administrativo para a constituição e identificação dos depósitos do Projeto II junto ao Banco Central e sua utilização para fins de relending. $\mathrm{O}$ mesmo quanto à utilização do New Money do Projeto I.

Claramente, a análise de tais disposições regulamentares não cabe no âmbito deste trabalho. Procurar-se-á, isso sim, ainda que sinteticamente, mostrar as grandes linhas ao longo das quais evoluiu a busca de mecanismos aptos ao equacionamento do problema do endividamento, consentâneos com as novas realidades por ele trazidas às esferas nacional e internacional.

\section{AS MODIFICAÇÕES NO ESQUEMA DE REESTRUTURAÇÃO.}

Como ficara patente, desde o início, o quadripé, montado em fevereiro de 1982, não poderia ser desmanchado em dezembro do mesmo ano, pois a natureza do problema não se compadecia de esquemas efêmeros para o seu equacionamento. E, assim, já em janeiro de 1983 repetia-se a dose com a assinatura de novos contratos, nos mesmos moldes dos anteriores, a vigorarem durante todo aquele ano.

Mesmo após o término desses contratos, a partir de 1985, seus mecanismos continuaram sendo aplicados por uma espécie de agreement informal, de sorte a continuar o Brasil a honrar o pagamento dos juros, mantendo, porém, em depósitos junto ao seu Banco Central, as parcelas do 
principal vencidas. As demais linhas dos acordos foram igualmente mantidas, exceção feita ao Projeto I New Money - que ficou definitivamente encerrado.

A situação assim se arrastou até 1986 quando um Amendment ao Deposit Facility Agreement foi assinado, destinado basicamente a validar a situação de fato vivida desde 1985, estendendo-a até a formalização de novo acordo, o que veio a ocorrer somente dois anos depois, em 22 de setembro de 1988, com a celebração de diversos contratos, dos quais o mais importante, naturalmente, foi o novo Deposit Facility Agreement, agora precedido da expressão "Multi Year" para significar que, finalmente, era reconhecida a natureza estrutural da crise e o longo prazo necessário para a sua superação. Daí a sigla MYDFA pela qual passou a ser designado. A demora em se chegar a este novo acordo, decorreu, em parte, da turbulência causada pela moratória unilateral decretada pelo Brasil em março de 1987, suspendendo o próprio pagamento dos juros.

Em sua essência o MYDFA mantém os mecanismos criados pelos anteriores DFAs, introduzindo, porém, entre outros, um conceito inovador, representado pela aceitação da conversão de parcelas do principal da dívida em investimento, porém com a aplicação de um deságio.

A conversão de crédito em capital sempre existiu no direito brasileiro. A própria Lei n. 4.131, de 1962 o diploma do capital estrangeiro - a prevê expressamente e, em tempos mais recentes, uma simples Carta-circular a de n. 1.125, de 1984 - do Banco Central a referendava, apenas estabelecendo obrigatoriedade de permanência no país dos fundos convertidos em capital pelo prazo de duração dos créditos que lhes deram origem, a fim de evitar que com a conversão fosse remetido como retorno de capital aquilo que seria irremissível como pagamento de dívida.

O conceito da conversão com deságio encontra sua origem no desenvolvimento de um mercado secundário para os títulos representativos da dívida externa brasileira, no qual os mesmos passaram a ser colocados com considerável redução de seu valor de face. Assim, em termos econômicos, cada credor já não poderia afirmar que possuísse efetivamente o valor nominal do seu crédito para pronta realização do mesmo. Estabeleceram-se, pois, no MYDFA, normas para essa conversão, refletidas subseqüentemente na Resolução n. 1.460 do Banco Central. E, com efeito, de março a dezembro do ano de 1989 
realizaram-se mensalmente os chamados leilões de conversão durante os quais eram apresentados "lances" expressos em percentagens de deságio que os credores estavam dispostos a oferecer para poderem converter seus MYDFAS depósitos no Banco Central em investimento de capital de risco. O deságio apurado nos leilões aplicava-se, também, à conversão de dívidas vincendas junto às próprias mutuárias brasileiras.

A necessidade de controle da base monetária, no entanto, fez com que tais leilões fossem indefinidamente suspensos, pois a conversão dos MYDFAs implicava, inexoravelmente, a liberação de fundos pelo Banco Central ao sistema econômico, pressionando, pois, os meios de pagamento, com imediata repercussão nas taxas inflacionárias que, à época - janeiro de 1990 - já iniciavam a marcha ascensional que levariam os índices de preços daquele ano a se aproximarem dos 90 ou $100 \%$.

Em termos de conversão restaram, apenas, as relativas a dívidas vincendas das empresas brasileiras, cuja efetivação, evidentemente, não implicaria qualquer sobrecarga dos meios de pagamento por já estarem os correspondentes recursos em mãos das mesmas empresas.

Por outro lado, o relending - utilização dos depósitos no Banco Central pelos bancos credores para fins de novos empréstimos em moeda estrangeira muito embora previsto no acordo, também deixou de ser implementado pelas mesmas razões, ou seja, para se evitar a saída de recursos líquidos do Banco Central a engrossar a base monetária.

Outro ponto importante, a merecer realce, é o da desvinculação total dos depósitos MYDFA junto ao Banco Central, dos empréstimos iniciais que lhes deram origem. $O$ cordão umbilical entre uns e outros que havia sido mantido pelos anteriores DFAs de 1983 e 1984 e com o Amendment de 1986 foi agora seccionado, de tal modo a não existir mais a menor vinculação entre os empréstimos originais e os depósitos atuais. Isso implica, por via de conseqüência, a completa liberação de quaisquer eventuais coobrigados nos empréstimos originais com relação aos depósitos abertos no Banco Central ao abrigo dos antigos DFAs, liberação essa que sempre se entendeu ter ocorrido, já que o mutuário original pagava, efetivamente, o seu débito, ficando, apenas, a faltar a fase final da remessa, substituída pelo depósito. No entanto, a partir de 1988 esse entendimento ficou formalmente consagrado, o que aqui se ressalta, 
por causa de seu significado emblemático. Ou seja, a desvinculação como que prenuncia a evolução futura das linhas institucionais a serem desenvolvidas nas negociações subseqüentes. Essa evolução se fará no sentido de uma despersonalização crescente dos títulos da dívida que deixarão basicamente de serem representados por contratos ou contas de depósito para caminharem em direção ao conceito de securitização, como adiante se verá.

Juntamente com o MYDFA, de 22 de setembro de 1988, outros instrumentos foram assinados, a fim de cobrir aspectos específicos do problema da dívida. Foram eles: Trade Commitment Letter, Commercial Bank Cofinancing Agreement, Parallel Financing Agreement, Interbank Commitment Letter, New Money Trade Deposit Agreement and Investment Bond Exchange Agreement.

No entanto, a sua duração foi relativamente curta como o relativo às linhas rotativas do Trade Finance, no antigo Projeto III, que deixaram de existir em 1991. O mesmo sucedeu com as linhas de depósitos interbancários do Projeto IV.

No entanto, por mais evoluído e refinado que tenha sido o novo Projeto II o MYDFA já plurianual, ele não impediu novas crises dentro da grande crise. Mais uma vez, a velha e renitente inflação brasileira, com renovada energia, alimentada pelo descalabro das finanças federais, impôs o seu tributo. As taxas mensais de alta de preços em escalada estratosférica, aproximando-se do patamar fatídico de $100 \%$, acabou por inviabilizar o próprio pagamento dos juros contratuais do MYDFA. A suspensão dos pagamentos, iniciada em meados de 1989, manteve-se até meados de 1991, quando a 20 de junho é assinado o 1989-1990 Interest Arrangements para promover o acerto desses juros. Delineia-se agora com clareza nos Arrangements a figura da securitização ou seja a emissão de securities, sob a forma de bonds, totalmente dissociados dos anteriores contratos e com novo esquema de juros com a passagem de boa parte deles para a categoria de alíquotas fixas ou mistas, conforme opção dos credores.

É bem verdade que, já em 1988, um dos acordos dos então assinados, o Investment Bond Exchange Agreement já previa a emissão pelo Brasil de bonds relativos a investimentos a serem trocados por alguns ítens da dívida externa. No entanto, tal acordo, além de limitado em seu escopo, virtualmente não teve aplicação, ficando mais como um esboço ou tentativa de inovação. 
Tais títulos apresentam-se sob modalidades diversas em função de prazos, redução do valor do principal e tipo de juro incidente, o que permite, em princípio, um certo balanceamento de vantagens e desvantagens seja para o país, como devedor, seja para os bancos, como credores, em função dos diversos cenários futuros para a evolução da taxa de juros no mercado internacional. Realizado, pelo Brasil, o pagamento da parcela de $25 \%$ devida em moeda, encontra-se, no presente (setembro de 1992), na fase de implementaçâo da emissão dos títulos autônomos referentes ao complemento de $75 \%$ a serem securitizados, com a escolha pelos credores de tipos e modalidades postos à sua disposição.

Ao mesmo tempo, chega-se à conclusão de um novo acordo, destinado a suceder o MYDFA, em bases também inteiramente novas, ou seja, na linha da securitização, agora também do principal, aplicando-se-lhe mutatis mutandis sistemática análoga à da há pouco utilizada para com o acerto referente aos juros.

\section{CONCLUSÕES.}

A análise, embora perfunctória, da evolução do tratamento jurídico dado à questão da dívida externa, permite extrair algumas conclusões, a seguir sintetizadas:

1 - A política econômica da nação exerce um papel preponderante sobre toda a atividade financeira tout court e, em particular, sobre a de caráter internacional. Está-se diante de um quadro típico de dirigismo contratual, caracterizado pela imposição de determinados parâmetros aos pactos privados, 0 que é feito, mesmo a nível de contratação internacional, por meio do mecanismo do registro de empréstimos e expedição dos certificados correspondentes pela autoridade monetária, o Banco Central.

2 O certificado de registro de empréstimo internacional, como também o certificado de registro de investimento estrangeiro e o de suprimento de tecnologia, são instrumentos típicos de direito econômico por envolverem um compromisso, em princípio, da autoridade monetária de fornecer as necessárias divisas para as remessas ao estrangeiro, desde que as linhas básicas da política 
econômica nacional tenham sido seguidas, conforme evidenciado pelos próprios certificados.

3 - Surge daí a dicotomia econômico-jurídica do risco que se biparte em risco comercial e risco político: microeconômico o primeiro; macroeconômico o segundo, decorrente este do descumprimento pela autoridade monetária - o Estado - do compromisso subjacente a cada certificado.

4 - Configurada esta última situação, surge a negociação não entre os particulares envolvidos na relação original, mas entre os particulares credores, de um lado, e o Estado, representado pela autoridade monetária - o Banco Central - de outro. Este, no entanto, formalmente se apresenta como um particular, contratando empréstimos, comprometendo-se a pagar juros e assim por diante, mas comprometendo-se, também - aí como autoridade monetária a emitir regulamentos internos coerentes com o pactuado com a outra parte os particulares credores.

5 Nesses contratos, os particulares que contrataram com o Banco Central - autoridade monetária - de antemão aceitam os termos dos futuros regulamentos a serem editados e que os obrigarão pelo poder de império da mesma autoridade, bem como a qualquer terceiro, agente econômico privado não parte dos acordos em questão, como no caso de uma empresa nacional que pretenda obter empréstimo, via relending, celebrando um Additional Loan Agreement ou, então, uma sociedade estrangeira que deseje se valer dos mecanismos de conversão da dívida para capitalizar uma sua subsidiária no Brasil.

6. Os instrumentos contratuais, acima analisados, não apenas consubstanciam o tratamento aplicável à questão da dívida externa, como também oferecem um fértil e interessante campo de pesquisa e de estudo teórico para o cultor do direito econômico, neste fim de século, por apresentarem as peculiaridades características deste campo do jurídico, cujas marcas assinalam e diferenciam os vários ramos do direito, interseccionando-o como em corte transversal.

7. Mais, talvez, do que um exemplo e eloqüente - da chamada économie concertée, tão realçada pelos tratadistas da matéria, eles parecem apontar, também, para a existência de um sistema com traços de auto-regulação, ao estilo de Teubner, a merecer uma análise atenta por parte dos estudiosos. 


\section{BIBLIOGRAFIA}

AUBANEL, G. Les mécanismes des euro-marchés. Bulletin trimestriel de la Banque de France, mai 1975.

BÉKERMAN, G. Les euro-dollars. Paris : Presses Universitaires de France, 1977.

-----Le marché euro-obligataire. Banque, mai et juin 1977.

-----Le marché international des capitaux (thèse complémentaire). Paris-1, 1976.

-.-.-Should the euro-currency market be controlled? SUERF, déc. 1980.

BELL, G. Les marchés d'euro-devises. Paris : Presses Universitaires de France, 1974.

BERTRAND, R. Economie financiere internationale. Paris : Presses Universitaires de France, 1971.

BLAISE, FOUCHARD \& KAHN. Les euro-credits. Paris : Librairies Techniques, 1981.

BRANSON, W. \& HILL, R. D. Mouvements de capitaux dans l'ensemble de la zone OCDE: une analyse économétrique. OCDE, 1971.

BURNS, A. F. The conditions of the world economy. The AEI Economist, 1986.

CHAMPION, P. \& TRAUMAN, J. Mécanismes de change et marché des eurodollars. Paris, 1978.

CLARK, T. B. Tackling the debt crisis. National Joumal, September 1986.

COULBOIS, P. Finance internationale. Cujas, 1979.

DE VRIES, B. A. Restructuring debtor economist: the trustees of Columbia University in the city of New York, 1984.

EINZIG, P. The euro-dollar market. Londres, 1975.

HERRING, R. \& MARSTON, R. Monetary interdependance among industrial countries: a study of interest rates linkages. Washington : Department of the Treasury, 1974.

HUSAIN, I. Recent experience with the debt strategy. Finance \& Development, December 1989.

IKLE, M. Die Schweiz als Internationaler Bank-und Finanzplatz. Zürich, 1970.

LATTRE, A. de. Les finances extérieures de la France. Paris : Presses Universitaires de France, 1958.

LIPFERT, H. Internationaler Devisen-und Geldhandel. Francfort, 1967. 
MAYER, H. Credit and liquidity creation in the international banking sector. BIS Economic Papers, n. 1, nov. 1979.

MCCLAM, W. D. US monetary aggregates, income velocity and the euro-dollar market. BIS Economic Papers, n. 2, avril 1980.

J. DU PRÉ DE SAINT-MAUR, Les euro-crédits financiers. Banque, juillet-août 1974.

PEREIRA, L. C. Bresser. Dívida externa: crise e solução. São Paulo : Brasiliense, 1989.

PROCHNOV, H. V. et al. L'euro-dollar, trad., 1971.

RIVOIRE, J. Les problèmes monétaires internationaux: avis et rapports du Conseil Économique et Social. Journal du Conseil Économique et Social, 28 janvier 1976.

STEM, C. H. The euro-dollar system. Harvard.

WEILLER, J. S. Économie internationale. Mouton, 1975.

WELLONS, P. A. Les emprunts des pays en développement sur le marché des euro-devises. OCDE, 1977. 502 pages. 